\title{
Observations on the paper by Prof. Trowbridge, "motions of atoms in the electrical discharge" (Phil. Mag. 5th series, vol. xxx. p.480, 1890)
}

\section{E. Wiedemann \& H. Ebert}

To cite this article: E. Wiedemann \& H. Ebert (1891) Observations on the paper by Prof. Trowbridge, "motions of atoms in the electrical discharge" (Phil. Mag. 5th series, vol. xxx. p.480, 1890), Philosophical Magazine, 31:190, 288-289, DOI: $10.1080 / 14786449108620106$

To link to this article: http://dx.doi.org/10.1080/14786449108620106

曲 Published online: 08 May 2009.

Submit your article to this journal $₫$

山 Article views: 2

Q View related articles ¿ 
islands which appear to be raised reefs comparable with those of Barbados, and show that these reefs occur through the whole length of the Antillean Chain, and indicate a recent elevation of at least 1300 feet, and in all probability of nearly 2000 feet. It appears improbable that each island was a region of separate uplift, and as a plateau of recent marine limestone also occurs in Yucatan, this carries the region of elevation into Central America, and it is reported that there are raised reefs in Colombia. The authors conclude that there has been contemporaneous elevation of the whole Andean Chain from Cape Horn to Tehuantepec and of the Antillean Chain from Cuba to Barbados. Before this there must have been free communication between the Atlantic and Pacific Oceans, which is confirmed by the large number of Pacific forms in the Caribbean Sea. Under such geographical conditions the great equatorial current would pass into the Pacific, and there would be no Gulf Stream in the North Atlantic.

2. "The Shap Granite, and the Associated Igneous and Metamorphic Rocks." By Alfred Harker, Esq., M.A., F.G.S., and J. E. Marr, Esq., M.A., Sec. G. S.

The authors describe the normal granite of the intrusion, and discuss the characters of certain variations from the usual type.

The dykes and sills of the neighbourhood are also considered; the similarity of some of these to certain inclusions in the granite is noticed; and reasons are given for supposing that many of the felsites and mica-traps of this region are connected with a magma which was intruded amongst the Lower Palæozoic rocks in preCarboniferous times, and with which the Shap granite is itself connected.

The metamorphic effects of the granite upon the surrounding rocks are then described. A remarkable set of changes produced in a series of andesites and another of rhyolites, with their respective pyroclastic rocks, is considered in detail, and the results of the metamorphism of the Coniston Limestone series and the Coniston Flags and Grits are given and compared with those obtained by other workers in Norway, the Harz Mountains, and elsewhere.

\section{Intelligence and Miscellaneous Articles.}

OBSERVATIONS ON THE PAPER BY PROF. TROWBRIDGE, " MOTIONS OF atoms IN THE ELECTRICAL DIscharge" (Phil. Mag. 5th series, vol. XXx. p. 480, 1890). BY E. WIEDEMANN AND H. EBERT.

TO the paper of Prof. Trowbridge cited above, in which he proves that the molecules in electrical discharges possess no motion of 
translation in the direction of the discharge, we beg to make the following historical observations :-

1. When von Zahn investigated the spectral lines of a dischargetube, in one case in a direction at right angles to the axis, and then in the direction of the axis itself, the lines were not displaced, although he was able to distinguish even the $\frac{l}{40}$ of the distance of the $\mathrm{D}$ lines. This displacement would have corresponded to a velocity of one geographical mile in the direction of the axis *.

2. Preliminary experiments of Tait, in which the spectra of a tube containing bromide of carbon were found to be the same both when parallel and at right angles to the discharge-tube, showed that the velocity must be far greater, about 90 geographical miles in a second.

3. But that it can neither attain the value obtained by von Zahn, still less a higher one, follows from the experiments of $\mathrm{E}$. Wiedemann and $H$. Ebert $\uparrow$, which were obtained both by the method of Fraunhofer's minima of the second class, as well as by the method of high interferences.

4. The method employed by Prof. Trowbridge, as he himself states, shows changes in the wave-length of $1 / 4000$; that used by Wiedemann and Ebert, of which, as well as of the other methods mentioned above, Professor Trowbridge makes no mention, shows a change of $1 / 834,000$ of the value. The latter is therefore about 200 times as sensitive as the former.

Erlangen, January 1891.

ON HERTZ'S ELECTRICAL VIBRATIONS IN AIR. BY E. SARASIN AND L. DE LA RIVE.

A very thin lead plate 2.95 metres broad and 2.8 metres high, was suspended vertically. The primary conductor was horizorital. and placed either at 5.7 or 9 metres distance from the lead plate, and parallel to it; its spark was formed in the perpendicular to the centre of the plate. The space in front of the lead plate was explored by means of a circular resonator, which was displaced along a divided scale on the normal to the lead plate. The scintilla at the break is, as observed by Hertz, stronger when the continuous part of the circuit in which the induction preponderates is in a loop, and the break is in a node, whereby for each node the break can be turned to or away from the reflecting lead plate. Close to the reflector is a node. With varions primary conductors and resonators of $1,0 \cdot 75,0.5,0.36,0.25$, and 0.20 metre in diameter, almost the same intermediate spaces were found as along wires. The velocity of propagation through air is thus essentially the same as with wires. In this case also the resonance is a multiple one;

* Wiedemann's ' Electricity,' vol. iv. p. 580.

$\dagger$ Wiedemann's Annalen, vol. xxxvi. p. 553, 1889. 